\title{
Implementing Blended Learning in an Impoverished Academic Institution Using a Bricolage Approach Model
}

\author{
Betchie E. Aguinaldo, Member, IACSIT
}

\begin{abstract}
The researcher implemented blended learning in an impoverished academic institution using a Bricolage approach model. The study resulted to high acceptability rate of e-learning usage despite of the socio-economic profile of the student's parents, unavailability of internet connection and inadequacy of technological resources of Isabela State University San Mateo Campus. This implies that blended learning can be implemented successfully using the right blend of online learning and face-to-face learning following the Bricolage approach model.
\end{abstract}

Index Terms-Bricolage, blended learning, developing countries, ciborra.

\section{INTRODUCTION}

Economic status is used as one of the indicators of an organization's image. Teaching and learning requires financial stability for universities as a learning organization [1]. The advent of technological advancement in education requires tremendous cost and the most barrier to learning as cited by [2]. Thus, developed countries reap the benefits offered by online technology commonly referred to as " $e$ learning". Whereas, with limited fund allocated to education in developing countries, the scarcity of hardware, software and internet connection resulted to limited learning.

\section{A. Socio-Economic Status in the Philippines}

Poverty is a major contributor in the illiteracy rate in any part of the world. According to the 2009 Official Poverty Statistics of the National Statistical Coordination Board (NSCB) of the Philippines released in February 2011, in the year 2009 a Filipino needs Php 974.00 (approximately \$21USD) of his monthly food needs and for him not to be considered poor, he needs to have a monthly income of Php 1,403 (\$30USD) [3].

Moreover, based on the Philippine's National Statistics Office's Final Results from the 2009 Family Expenditure and Income Survey, "Families in the bottom 30\% income group, which are considered poor families, has an average yearly earnings of Php 62,000 (\$1,344USD). On a monthly basis, the reported average income of the families in the bottom 30\% income group was Php 5,200 (\$113USD) in 2009." Also in the same Survey, it was found out that families who are considered poor spent Php 64,000 (\$1,387USD) for their sustenance, hence, they are Php 2,000 (\$43USD) short of their average yearly income compared to their necessary spending [4].

Manuscript received September 30, 2012; revised January 13, 2013.

Betchie E. Aguinaldo is with Isabela State University, San Mateo, Isabela, Philippines (e-mail: betchie_aguinaldo@yahoo.com).
In the international context, the survey results correlate with the income classification of the Philippines based on the World Bank data as lower middle income class with a gross national income (GNI) per capita of $\$ 1,026-\$ 4,035$ (as of 2009, the peso-dollar conversion was Php 46.14 to $\$ 1.04$ USD) [5], [6]. While Southeast Asia is approximately half of the world's poor which has $85 \%$ of the population (1.3 billion of the population) who lives less than \$2USD a day based on World Bank data [7], poverty rates is higher in the Philippines compared to other ASEAN countries [8]. In 2009, NSCB released that one in four Filipinos (total of 23.14 million) lives in less than \$2USD a day [9].

The income status of the Philippines impacted the education development. As technological advancement soar, millions of Filipinos are lagging behind.

\section{B. E-Learning in the Philippines}

Philippines, as one of the developing countries experiences the scarcity of technological resources needed for education. Hardware, software, internet connection and network infrastructure are just some of the basic necessities for an academic institution to operate on a true "e-learning" environment.

Students in Metro Manila, capital of the Philippines, "are among the digital poor with fewer opportunities to access and contribute to digital content" as compared to other International Association for Evaluation of Educational Achievement (IEA)-surveyed countries [10]. Most secondary schools in Metro Manila, claimed that Information and Communication Technology (ICT) is integrated and emerged in teaching and learning however, teachers frequently used ICT as productivity tools [11]. ICT integration to teaching and learning evidently are left behind.

\section{E-Learning in Rural Area of the Philippines}

Eighty-eight million ( 88 million) live in rural areas in the Philippines, more than $80 \%$ of the country's population is poor living in rural areas [12]. Majority of the population includes small-scale and landless farmers.

Isabela, the $2^{\text {nd }}$ largest province of the country in terms of land area, agriculture is the major industry. Isabela has a state university with 9 campuses. The current status of ICT in an urbanized area of the Philippines serves as a good foundation to describe the status of Isabela State University (ISU) in terms of "e-learning accessibility". As a state university subsidized by the government, ISU has limited technological facilities such as hardware for computer laboratory, education software, poor network infrastructure, inaccessible internet connection (slow bandwidth) and no internet connection.

In terms of class size, ISU has a minimum of 40 students maintained in each class. During a 3-hour computer 
laboratory class, students are divided into batches for them to be accommodated in the computer laboratory with only 20 computer units and no internet connection. Some of the faculty members also act as computer technicians in case of computer breakdown. As a result broken computers are not fixed promptly, hence, teachers are forced to divide a class into smaller number of students in order to accommodate them in the functioning computer units thus depriving them of enough computer laboratory time per week.

\section{Blended Learning}

Blended learning has been used in literature since 1999 [13] as it also pertains to the integration of any electronic media in teaching and learning. In the $20^{\text {th }}$ century, it is commonly defined as combination, convergence, utilizing both online learning and face-to-face learning [14]-[17]. It is the right mix and match of technology to teaching to achieve learning.

\section{E. ICT and Bricolage Approach Model}

Rural areas of developing countries are always affected by technological advancement, thus, various ICT models are developed by researchers to integrate ICT to financially and technologically deprived areas. It is a common belief that ICT uplifts standard of living: in terms of economic and human development particularly on education advancement. India, Pakistan, Ethiopia are some of the developing countries where ICT business models are developed to uplift the standard of living in terms of disseminating information. Mainly ICT models aim to educate people in rural areas.

Installation of Rural Kiosk Machine (RKM) to rural community center/school was proposed to be the server of all information that will be accessed by the community (farmer and non-farmer), teacher and children in India (Model for ICT rural education) [18] and Pakistan (Model for sustainable ICT Project Rural Pakistan) [19] rural area. RKM contain textual, audio and video information on agriculture, health and education. While ICT training center (ICT-TC) was used to provide training to the people during evening. Furthermore, the business model used by TelNet Group, IITM, India has a resemblance with the previous case, an ICT Kiosk is owned and driven by local entrepreneur to provide ICT services such as computer education, internet services, e-government and video conferencing such as tele-medicine, vet care, e-learning and e-agriculture [20].

In 2010 Bass developed ICT Maturity Model used in five public universities in Ethiopia. The model provides guidelines to develop an ICT framework for low-income countries [21]. The maturity model composed of iterative cycles of identifying a problem, planning, acting and evaluating. Bass developed a strategic plan laid in the ICT Maturity Model composed of eight maturity levels and resource milestones. Overall, the maturity model is used to assess the university's ICT environment, teacher and students skill that is needed to address the findings of the assessment using the maturity model.

Still, Bass ICT Maturity model failed to answer the problem on how poor students from developing countries would be able to cope with fast developing technological tools and devices applied inside the classroom. How can a university which has no internet access be able to use e-

\section{learning?}

Complaints from education stakeholders from poor academic institutions are prevalent. Instead of repetitively stating the obvious status of poor academic institutions on their response to technological innovation, "innovation must be embraced as bricolage", Bricolage came from the Latin word "bricola" which means tinkering through the combination of resources at hand [22]. Utilization of existing resources and organization of practices provide practical solutions to existing problems.

The Bricolage Approach Model for blended learning was developed from empirical data experienced by the students using e-learning and the author.

The initial stage of the bricolage approach model is a study on the development of e-learning tool called as "eARAL" (ARAL is a Filipino language of the English word "study") [23]. It was implemented in a university, which has no internet access and limited computer resources.

The study was presented in an international conference in Thailand, wherein the participants and researchers became interested on the implementation of e-ARAL to a poor academic institution. Evaluation, is the next study conducted wherein Technology Acceptance Model (TAM) of Davis (1989) of e-ARAL was used [24]. To sustain the existence of e-learning tool in the university, ICT sustainability types were applied to assess the university, teachers, students, community and parents' socio-economic profile. The output of matrix of problems and solutions using ICT sustainability types were used in the Bricolage Approach model.

Ciborra's bricolage, improvisation and hacking was applied in the development of the model. The Bricolage approach model hacked other models applicable to real situation of the university, improvise methodologies to access technologies needed for e-learning and apply bricolage. The model was developed using empathy, understanding end-users' need and real situation of poor academic institution.

\section{F. Goal and Research Questions}

The researcher is interested in the application of Bricolage to an impoverished academic institution. In this study, ISU San Mateo campus was used in the experiment because it has no internet connectivity and limited computer units in the computer laboratory. Blended learning will be implemented using Bricolage approach model. The researcher attempted to answer the following research questions: (1) What is the structure of Bricolage Approach Model?; (2) What is the status of ISU in terms of ICT sustainability?; (3) What is the socio-economic status of the parents of the students who are subject of the study?; (4) How can blended learning be implemented in an impoverished academic institution?; and (5) What is the acceptability rate of students in using the e-learning tool?

\section{G. Theoretical Framework}

The researcher adapted the ICT sustainability types to assess the current status of the university in terms of its existing resources. Matrix of problems and solutions is created to determine the problem and recommended solutions to address the stated problem. Bricolage Approach Model consists of four phases: (1) identification of resources; (2) planning phase of resources; (3) 
implementation phase; (4) evaluation phase. Identification of resources is used to identify technological resources, stakeholders and available place and time wherein online learning will take place. Planning phase of resources involves schedule of online access as well as the innovative teaching strategies that will be used for online and face-toface learning. Implementation phase is the actual use of innovative strategies by the researcher and subject of the study. Evaluation phase is used to monitor the frequency of usage of the subject to determine the acceptability rate of eARAL.

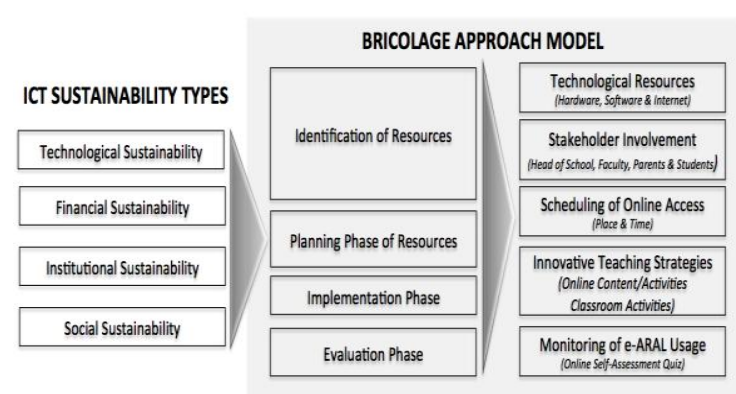

Fig. 1. Bricolage approach model.

\section{H. Significance}

This study is significant because it provides students, teachers and most importantly top-school management with the possibility of implementing blended learning to impoverished academic institution in terms of technology resources needed for online learning. Methodology used in this study can serve as guidelines prior to the implementation of blended learning to impoverished academic institution. Result of the study can be used by other researchers to improve the Bricolage approach model and find innovate ways to use the technology in teaching and learning process in a developing country.

\section{MethodOLOGY}

The researcher used a combination of assessment, survey questionnaires and orientation meeting with the head of the campus, faculty, students and their parents before the implementation of Bricolage approach.

\section{A. Assessing University's ICT Sustainability}

There are five ICT sustainability types that include technological, financial, social, institutional and environmental sustainability as least considered as cited by [25]. Environmental sustainability type was not included in the study considering that the same pertains to disposal of old computers and equipment to which the university has nothing to dispose of considering that it is still using obsolete and old computers.

\section{B. Subject of the Study}

The subject of the study consists of 45 regular freshmen who are taking Bachelor of Science in Information Technology enrolled in Introduction to Information Technology course. Regular students are those who are taking the offered subjects for the semester.

The 45 regular freshmen are those who were allowed by their parents to access the internet in internet café' during weekends as per schedule of e-ARAL.

\section{Construction of Questionnaire}

The researcher developed a socio-economic survey questionnaire that includes level of parent's educational background as well as their monthly net income.

\section{Orientation Meeting and Self-Paced Training}

An orientation meeting with the campus administrator (head of the campus) and faculty, students and their parents is conducted prior to the implementation of blended learning. The campus administrator and faculty were oriented on the implementation of the e-ARAL. Orientation about the features and functions of the latter was conducted on the subject. Training on actual use of e-ARAL was done independently by the subject in an internet café using the training materials provided by the researcher. A parents' orientation of the subject was conducted to gather the insights of parents' experiences of subject's attitude towards internet usage. e-ARAL's benefit were discussed to the parents. They were also informed on the subject's e-ARAL schedule at which time they will be required to access the internet.

\section{E. Development of Blended Learning Activities}

Activities are developed for online learning and face-toface learning such as follows:

\begin{tabular}{|c|c|}
\hline Online Learning & Face-to-Face Learning \\
\hline $\begin{array}{l}\text { 1. e-ARAL lectures are organized by } \\
\text { module displayed in portable data } \\
\text { format (pdf), } \\
\text { 2. Seven (7) timed online self- } \\
\text { assessment quiz for each module } \\
\text { 3. uploading area of online activities. } \\
\text { 4. SMS capability to inform the subject } \\
\text { on recent online activities and } \\
\text { announcements }\end{array}$ & $\begin{array}{l}\text { 1. Group Presentation } \\
\text { 2. Word Hunting } \\
\text { 3. Pinoy Henyo (Filipino Genius Game) } \\
\text { 4. Concept Mapping } \\
\text { 5. Brain Scratch }\end{array}$ \\
\hline
\end{tabular}

\section{F. Data Gathering}

The researcher gathered data during the parents' orientation meeting. Survey questionnaire was floated after the conduct of parents' orientation meeting. e-ARAL's database was retrieved to gather the frequency of subject's usage of online learning tool. Frequency of usage refers to the number of times the subject answered the online selfassessment quiz based on the given due dates as this requires interaction.

\section{G. Data Analysis}

The researcher used frequency and percentage to describe the socio-economic profile of subject's parents and acceptability rate of the subject. Acceptability rate is measured by using the percentage of students accessing the e-ARAL self-assessment quiz retrieved from the database.

\section{RESULT AND DISCUSSION}

\section{A. Assessment of ICT Sustainability of the University}

The researcher created a matrix of problem and solution using the ICT sustainability types to determine the current status of the university. Based on Fig. 2, obsolete computers, numerous programs are installed in the existing computers, 
technical maintenance of computer, limited computer and no internet connection are the problems encountered under technological sustainability. Due to unavailability of internet connection to conduct the training of e-ARAL, it is recommended to provide e-ARAL training handouts and let students conduct self-paced training in internet cafés.

Delayed release of campus budget for technical maintenance and procurement of additional computers is being encountered in terms of financial sustainability. Furthermore, students are on budget constraint in terms of internet/computer rental fee. It was therefore recommended to group the students into three (3) to pay the fifteen pesos per hour (Php15.00/hr equivalent to $\$ 0.36 \mathrm{USD} / \mathrm{hr}$ ) internet rental fee for them to read the uploaded module and answer the ten (10) minutes self-assessment quiz

Institutional and social sustainability covers the lack of participation of the stakeholders. Proper coordination with the head campus and faculty is conducted to gather the support on the implementation of Bricolage approach model. Parents' orientation meeting is organized to involve them on the implementation by allowing the subject to spend time in using e-ARAL particularly during weekends.

\begin{tabular}{|c|c|c|c|}
\hline \multicolumn{3}{|c|}{ MATRIX OF PROBLEMS AND SOLUTIONS } & \multirow{2}{*}{$\begin{array}{c}\text { BRICOLAGE APPROACH OF } \\
\text { TEACHING }\end{array}$} \\
\hline TYPES OF ICT SUSTAINABILITY & $\begin{array}{l}\text { PROBLEMS IN ISABELA } \\
\text { STATE UNIVERSITY }\end{array}$ & RECOMMENDED SOLUTION & \\
\hline $\begin{array}{l}\text { Technological Sustainability } \\
\text { - is the ability for a technology to } \\
\text { exist for a long period of time } \\
\text { without major shifts in hardware or } \\
\text { software affecting its availability and } \\
\text { durability }\end{array}$ & $\begin{array}{l}\text { - Obsolete computers } \\
\text { - Too many programs } \\
\text { installed in the computer } \\
\text { - Technical maintenance of } \\
\text { computer } \\
\text { - Limited computer } \\
\text { - No internet Connection }\end{array}$ & $\begin{array}{l}\text { Computer/internet rental } \\
\text { - Set schedule of online } \\
\text { activities } \\
\text { Immediate access to } \\
\text { computer } \\
\text { Immediate address to } \\
\text { technical problems }\end{array}$ & $\begin{array}{l}\text { 1. } \begin{array}{l}\text { Provide e-ARAL (Blended } \\
\text { Learning Environment Tool) } \\
\text { handouts }\end{array} \\
\text { 2. Advise to go to Internet } \\
\text { café Every last hour of } \\
\text { computer laboratory } \\
\text { schedule }\end{array}$ \\
\hline $\begin{array}{l}\text { Financial Sustainability } \\
\text { equal access for those cannot } \\
\text { afford to pay access }\end{array}$ & $\begin{array}{l}\text { - Budget constraint in terms } \\
\text { of internet/computer } \\
\text { rental fee } \\
\text { - Delayed release of campus } \\
\text { budget for technical } \\
\text { maintenance of computer }\end{array}$ & $\begin{array}{l}\text { Group students to support } \\
\text { rental fee } \\
\text { Students rent computer and } \\
\text { internet outside the } \\
\text { university }\end{array}$ & $\begin{array}{l}\text { Students were grouped into three } \\
\text { Purpose: } \\
\text { 1. Computer/Internet Rental } \\
\text { Fee Distribution in the } \\
\text { Internet Cafe } \\
\text { 2. Group Activity during face- } \\
\text { to-face discussion }\end{array}$ \\
\hline $\begin{array}{l}\text { Social Sustainability } \\
\text { - requires user buy-in and } \\
\text { participation, taking into account } \\
\text { local traditions, considering } \\
\text { differences within communities, } \\
\text { empowering marginalized groups, } \\
\text { sharing and aligning goals with local } \\
\text { people and adapting to evolving } \\
\text { community needs. } \\
\text { Institutional Sustainability } \\
\text { - is closely related to social } \\
\text { responsibility }\end{array}$ & $\begin{array}{l}\text { Participation of } \\
\text { stakeholders: } \\
\text { 1. Head of the Campus } \\
\text { 2. Faculty } \\
\text { 3. Students } \\
\text { 4. Parents }\end{array}$ & $\begin{array}{l}\text { Involve the parents, } \\
\text { teachers and students } \\
\text { through orientation and } \\
\text { meetings }\end{array}$ & $\begin{array}{l}\text { 1. Approval from the Campus } \\
\text { Administrator } \\
\text { 2. Send letter and conduct } \\
\text { parent's orientation } \\
\text { meeting }\end{array}$ \\
\hline
\end{tabular}

Fig. 2. Matrix of problem and solution.

\section{B. Parent's Socio-Economic Profile}

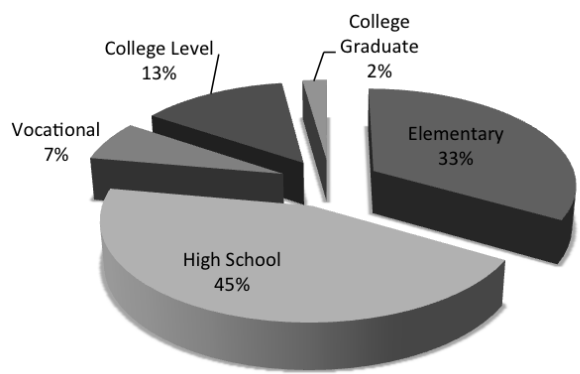

Fig. 3. Parent's educational attainment.

The researcher categorized parent's socio-economic profile to three (3) namely: (1) parent's educational background, (2) occupation, and (3) monthly income. Fig. 3 shows that $45 \%$ of parents are secondary school (high school) graduates, followed by $35 \%$ elementary graduates (grade 1 to grade 6). More than half of the parents were not able to enter in college. The percentage correlates with the finding in Fig. 4 and 5 wherein $67 \%$ of the parent's are farmer and $76 \%$ are earning income which range from Php1,000.00 - Php5,000.00 per month (\$25USD $\$ 122$ USD/month) indicated as the lowest bracket in the survey questionnaire.

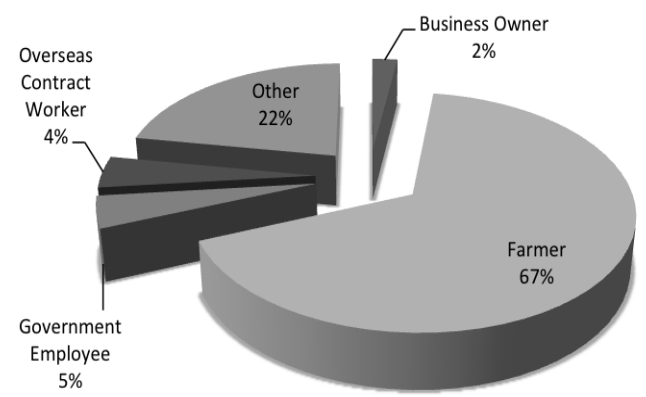

Fig. 4. Parent's occupation.

Further analysis shows that majority of the students enrolled in the university belong to the poorest family in the community based on Family Expenditure and Income 
Survey of NSCB. Moreover, the recommended parents' involvement on the implementation of blended learning is necessary to get the commitment and support of the parents despite of their financial status as parents' socio-economic profile affects students' school performance. The researcher considered the parents' monthly income since internet rental fee will incur cost to the subject thus recommended to be grouped into three (3) to share the internet rental fee among themselves.

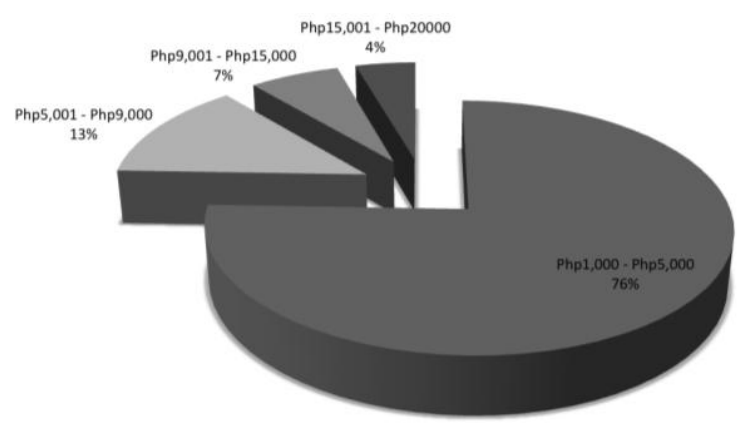

Fig. 5. Percentage of parent's monthly income.

\section{Acceptability Rate of e-ARAL}

The researcher measured the acceptability rate of eARAL by the number of subject who took the timed online self-assessment quiz. The answers on the self-assessment quiz will be used on the activity during face-to-face learning. Seven self-assessment online quizzes were developed in eARAL discussed during face-to-face learning. Fig. 6 shows that on the initial online quiz only 25 out of 45 or $55.6 \%$ of the students logged in to e-ARAL and took the online quiz. This implies that the remaining students were hesitant to use the e-ARAL. The initial result implies that the technological comfort level of the subject existed. The result also shows that individual characteristics of the subject plays an important role in the success and failure of implementing elearning which correlates with the findings of [26], [27].

It can be gleaned from Fig. 6 that with the continuous usage of e-ARAL through online self-assessment quiz, a gradual increase of subject who took the online quiz resulted to $86.7 \%$ or 39 out of 45 students who took the last developed online quiz. Further analysis shows that with the immediate application of lesson learned from online learning during face-to-face learning increases motivation thus, resulted to technological confidence taken from the continuous usage of e-ARAL.

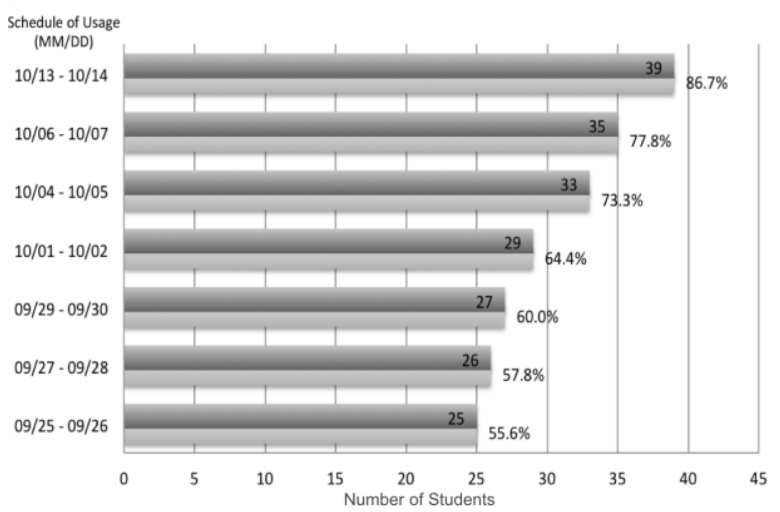

Fig. 6. Percentage of subject's acceptability rate of e-ARAL.
Finally the displayed positive result of the implementation of blended learning in an impoverished academic institution proved that with the right blend of online learning and face-to-face teaching strategies, a blended learning can be applied successfully in the teaching and learning process.

\section{CONCLUSION}

Based on the data gathered in this study, it is clear that assessing the current status of the ISU using ICT sustainability types serves as a concrete foundation on the creation of plan and solution on the implementation of blended learning. Involvement of main stakeholders that include head of the campus, faculty, parent and students contribute to the success of the implementation of blended learning. Surveying parents' socio-economic profile also plays an important role on the strategy of implementation. Moreover, the researcher was able to determine the incurred cost that will be added to students' stipend, thus the recommendation in terms of financial sustainability contributes to the increase of students who use the elearning tool (i.e. e-ARAL). Stated face-to-face learning activities increase motivation of the subject to use the online learning tool as the lessons learned from online learning were used in face-to-face learning which indeed a right blend of online and face-to-face learning activities results to successful blended learning.

\section{RECOMMENDATION FOR FURTHER STUDY}

The researcher opens her study for developing countries specifically to impoverished academic institutions to further develop the Bricolage approach to utilize the existing resources enable to cope up gradually on the continuing innovations on educational technology.

Furthermore, it is also interesting to measure the academic performance as well as other competency skills that can be gained using Bricolage approach.

\section{REFERENCES}

[1] A. B. Youssef and M. Dahmani, "The Impact of ICT on Student Performance in Higher Education: Direct Effects, Indirect Effects and Organizational Change," Revista de Universidad y Sociedad del Conocimiento, vol. 5 no. I, 2008 pp. 45-56.

[2] J. Sim, P. Powell, and R. Vidgen. (2005). E-learning and the Digital Divide: Perpetuating Cultural and Socio-Economic Elitism in Higher Education. [Online]. Available: http://www.is2.1se.ac.uk/asp/aspecis/20050141.pdf

[3] R. A. Virola, "2009 Official Poverty Statistics," presented at the PressCon on the 2009 Official Poverty Statistics, NSCB Operation Room, Makati City, Philippines, February 8, 2011.

[4] Families in the Bottonm 30 Percent Income Group Earned 62 Thousand Pesos in 2009 (Final Results from the 2009 Family Income and Expenditure Survey), National Statistics Office, February 4, 2011.

[5] The World Bank. How we Classify Countries. [Online]. Available: http://www.data.worldbank.org/about/country-classifications.

[6] The World Bank. Philippines. [Online]. Available: http://www.data.worldbank.org/country/philippines.

[7] A Dollar a Day::Poverty Overview. Oracle Think Quest Education Foundation. [Online]. Available: http://www.library.thinkquest.org/05aug/00282/over_world.htm

[8] P. Gerson, "Poverty, Income Distribution, and Economic Policy in the Philippines," Copyrighted International Monetary Fund, February 1998. 
[9] A. F. Presse. (2011). One in 4 Filipinos live on a dollar a day. Inquirer.net. [Online]. Available: http://www.business.inquirer.net/money/breakingnews/view/2011020 8-319235/One-in-4-Filipinos-live-on-dollar-a-day

[10] M. M. Rodrigo, "Quantifying the Divide: a comparison of ICT usage of schools in Metro Manila and IEA-surveyed countries," International Journal of Educational Development, December 25, 2005, pp. 53-68.

[11] M. M. Rodrigo, "Tradition or transformation? An evaluation of ICTs in Metro Manila Schools," Information Technology for Development, IOS Press, 2003, pp. 95-122.

[12] Rural Poverty in the Philippines. IFAD. [Online]. Available: http://www.ruralpovertyportal.org/country/home/tags/philippines

[13] J. Holden. (2007). Blended Learning: Instructional Media \& Pedagogical Considerations. [Online]. Available: http://www.slideshare.net/jtholden/developing-a-blended-learningstrategy-instructional-media-pedagogical-considerations

[14] M. Simpson. Attempting to Realize the Potential of Blended Learning: An Initial Teacher Education Study. in Proc. ascilite 2008 Melbourne. [Online]. Available: http://www.ascilite.org.au/conferences/melbourne08/procs/simpson.p df

[15] R. Lynch and M. Dembo, "The Relationship Between Self-Regulation and Online Learning in a Blended Learning Context," in Proc. the International Review of Research in Open and Distance Learning, vol. 5, no. 2,2004

[16] C. Dziuban, J. Hartman, and P. Moskal. "Blended Learning," Educause Center for Applied Research, Research Bulletin, 2004, issue 7, pp. 2.

[17] K. Precel, Y. Eshet-Alkalai, and Y. Alberton, "Pedagogical and Design Aspects of a Blended Learning Course," The International Review of Research in Open and Distance Learning, vol. 10, no 2, 2009.

[18] N. K. Roy, "ICT - Enabled Rural Education in India," International Journal of Information and Education Technology, vol. 2, no. 5, October 2012, pp. 525-529.

[19] K. Sattar, "A sustainable model for use of ICTs in rural Pakistan," International Journal of Education and Development using Information and Communication Technology, vol. 3, issue 2, pp. 116124.

[20] A. Jhunjhunwala, N. Sujatha, and R. Anuradha. (September 2004), Enabling Rural India with ICT Initiatives. Telnet Group, IIT Madras,
India.

[Online].

Available:

http://www.itu.int/osg/spu/ni/digitalbridges/presentations/12Jhunjhunwala.pdf

[21] J. M. Bass. (2010). A New ICT Maturity model for Education Institutions in Developing Countries. Center for Development Informatics Institute for Development Policy and Management, SED. [Online].

Available: http://www.sed.manchester.ac.uk/idpm/research/publications/wp/di/d ocuments/di_wp44.pdf

[22] C. Ciborra, Labyrinths of Information Challenging the Wisdom of Systems, Oxford University Press, 2002, ch. 3, pp. 29-53.

[23] B. Aguinaldo, "Development of Blended Learning Environment Tool," in Proc. International Conference Innovative Research in a Changing and Challenging World, Thailand, 2012, pp. 23.

[24] B. Aguinaldo, "The Bricolage Approach of Teaching," International Journal of Education, IAMURE Press, vol. 3 July 2012, pp. 150-161.

[25] M. Ali and S. Bailur, "The Challenge of "Sustainability" in ICT4D Is Bricolage the Answer?" in Proc. 9th International Conference on Social Implications of Computers in Developing Countries, Sao Paulo, Brazil, May 2007.

[26] A. Andersson and A. Grönlund. (2009). A Conceptual Framework for E-Learning in Developing Countries: A Critical Review of Research Challenges. The Electronic Journal on Information Systems in Developing Countries. [Online]. Available: http://www.ejisdc.org/ojs2/index.php/ejisdc/article/view/564

[27] D. Aggarwal, "Role of e-Learning in A Developing Country Like India," in Proc. 3rd National Conference India, New Delhin, India, February 26-27, 2009.

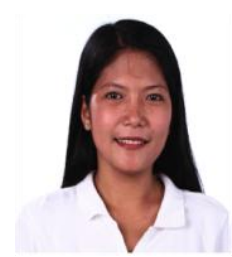

Betchie E. Aguinaldo is a full-time IT faculty of Isabela State University San Mateo Campus and designated as Campus Research Development Extension and Training coordinator. Her research papers are accepted for oral presentation in several international conferences held in Hong Kong, Thailand and Philippines. She is currently involved on the development of web-sms based educational services for Isabela State University and an experimental study of $21^{\text {st }}$ century learners and teaching skills using Bricolage Approach model in a blended learning environment. 